\title{
The dynamics of dengue virus serotype 3 introduction and dispersion in the state of Bahia, Brazil
}

\section{Paulo Roberto Santana de Melo/*, Eliana Almeida Gomes Reis, Isolina Allen Ciuffo**, Mônica Góes, Ronald Edward Blanton***, Mitermayer Galvão dos Reis/ ${ }^{+}$}

Centro de Pesquisa Gonçalo Moniz-Fiocruz, R. Valdemar Falcão 121, 40295-001 Salvador, BA, Brasil *Universidade Estadual de Santa Cruz, BA, Brasil **Laboratório Central do Estado da Bahia, Salvador, BA, Brasil ***Case University, Cleveland, OH, USA

By 2002, dengue virus serotype 1 (DENV-1) and DENV-2 had circulated for more than a decade in Brazil. In 2002, the introduction of DENV-3 in the state of Bahia produced a massive epidemic and the first cases of dengue hemorrhagic fever. Based on the standardized frequency, timing and location of viral isolations by the state's Central Laboratory, DENV-3 probably entered Bahia through its capital, Salvador, and then rapidly disseminated to other cities, following the main roads. A linear regression model that included traffic flow, distance from the capital and DENV-1 circulation $\left(r^{2}=0.24, p=0.001\right)$ supported this hypothesis. This pattern was not seen for serotypes already in circulation and was not seen for DENV-3 in the following year. Human population density was another important factor in the intensity of viral circulation. Neither DENV-1 nor DENV2 fit this model for 2001 or 2003. Since the vector has limited flight range and vector densities fail to correlate with intensity of viral circulation, this distribution represents the movement of infected people and to some extent mosquitoes. This pattern may mimic person-to-person spread of a new infection.

Key words: dengue - emerging diseases - surveillance - Aedes aegypti - public health - modeling

Dengue viruses are mosquito-borne RNA viruses of the Flaviviridae family. The four closely related serotypes (DENV-1-4) are thought to represent at least three independent introductions into human populations from sylvatic primates, the most recent (DENV-1) occurring within the last century (Wang et al. 2000). Dengue is one of the most important re-emergent infectious diseases and one of the most serious health problems affecting tropical and subtropical regions of the Americas (McBride \& Bielefeldt-Ohmann 2000, Guzman \& Kouri 2002). All four serotypes cause dengue fever (DF), a febrile illness characterized by severe joint and muscle pains, and in some cases, the potentially fatal dengue hemorrhagic fever (DHF) and dengue shock syndrome (DSS). The wide distribution of the mosquito vector Aedes aegypti in the tropics and subtropics results in the exposure of approximately 2.5 billion individuals to dengue infection yearly (Mackenzie et al. 2004).

Consistent with this, dengue viruses are the most common, important Flavivirus causing human disease in Brazil (Figueiredo 2000). In the last 14 years, Brazil has accounted for nearly $70 \%$ of the $3,141,850$ reported cases of DF in the Americas in the last five years (PAHO 2003). Some viral serotypes and the mosquito vector are now distributed throughout the country, and dengue outbreaks occur in all regions, especially the most populated areas, such as in the state of Bahia (BA). By the

Financial support: Fiocruz (PDTSP), CNPq, NIH(AI056263-01)

${ }^{+}$Corresponding author: miter@cpqgm.fiocruz.br

Received 29 May 2007

Accepted 28 November 2007 end of 2001, BA had only experienced epidemics with DENV-1 and DENV-2. Both of which were actively circulating when DENV-3 was introduced in 2002 and produced the first cases of DHF in BA. In 1987, DENV-1 was isolated for the first time in BA in the city of Ipupiara, located in the center of the state (the Chapada Diamantina region) (Vasconcelos et al. 2000). A second serotype, DENV-2, was introduced in 1995 in the extreme south of the state, although its exact point of introduction was not identified. During these initial epidemics in BA, the dynamics of introduction and subsequent spread of the infection could not be followed statewide, since the necessary public health protocols and the mechanism for viral isolation were not available. These were introduced in 1995 with development of a special unit at the state of Bahia's Central Laboratory (LACEN) for DENV isolation. In this study, we used the information from viral isolations at the LACEN from 2001 to 2003 to assess the dynamics of circulation of DENV serotypes in BA before, during and after the first introduction of DENV-3.

\section{MATERIALS AND METHODS}

Study site - BA is the fifth-largest Brazilian state in territorial extension and comprises $6.64 \%$ of the total area of the country. BA has 13,323,212 inhabitants with nearly $25 \%$ concentrated in the metropolitan area close to Salvador, the state's capital. Approximately $69 \%$ of the state is considered arid or semi-arid. By contrast, the $1,183 \mathrm{~km}$ long coastline is generally tropical and humid. Urbanization in BA is marked by concentration of the overwhelming part of the urban population in the capital, thus making Salvador the only city in the state whose population exceeds 500,000. Nevertheless, the state is also characterized by the dispersion of the population in hundreds of smaller urban centers. In the last two de- 
cades, there has been explosive growth of medium-sized urban centers (cities with more than 100,000 inhabitants). This has strengthened interurban networks and facilitated individual movements for commerce and migration. Although the majority of the state's territory is agricultural, there is a good level of infrastructure with electricity and paved roads throughout most of its area.

Sampling - For administrative and epidemiologic purposes, the state is divided into municipalities, which are the basic reporting unit for the State Secretariat of Health (SSH). Dengue is a reportable disease in Brazil. The secretary of health in each municipality is responsible for collecting serum from each suspected case of dengue within five days of onset of symptoms, and sending this on to the LACEN for viral isolation and serology. All data were obtained directly from the LACEN or online public databases of the Brazilian government in 2004. In the analysis, the simplifying assumptions were made that the only difference between municipalities was the frequency with which serum was collected from suspected cases, and errors were not systematic, but random.

Viral isolation - Viral isolation was performed by inoculation of an Aedes albopictus C6/36 cell line with $25 \mu \mathrm{l}$ of undiluted acute serum. The cell line was then incubated for seven days at $32^{\circ} \mathrm{C}$ in Leibovitz's medium supplemented with $5 \%$ fetal calf serum. After fixation to slides in quadruplicate with cold buffered acetone, the cells were incubated with serotype-specific monoclonal antibodies for each of the four serotypes followed by fluorescein conjugated anti-mouse antibodies. The slides were then scored as positive or negative by fluorescent microscopy (Gubler et al. 1984).

Statistical analysis - Since municipalities differed in their efficiency of submitting samples, a correction factor was calculated for each community for each month. The efficiency with which each municipality would send samples was calculated as the number of serum samples submitted for viral isolation divided by the number of cases notified for the month. The median efficiency for all municipalities was used to correct the

\section{TABLE I}

Dengue virus serotype 3 (DENV-3) circulation $^{a}$ in 2002 was associated with distance from Salvador, traffic flow and DENV1 circulation in the state of Bahia

\begin{tabular}{lccc}
\hline Model & Adjusted $^{2}$ & $(\mathrm{p})$ & ANOVA \\
\hline $\begin{array}{l}\text { Distance from Salvador } \\
\text { Distance from Salvador, }\end{array}$ & 0.138 & 0.004 & 0.004 \\
$\begin{array}{l}\text { traffic flow } \\
\text { Distance from Salvador, }\end{array}$ & 0.202 & 0.032 & 0.002 \\
\begin{tabular}{l} 
traffic flow, DENV-1 \\
\hline
\end{tabular} & 0.235 & 0.087 & 0.001 \\
\hline
\end{tabular}

$a$ : linear multiple regression on log-normalized circulation intensity for DENV-3 (standardized isolates/100,000) per municipality for 2002. Distance from Salvador, traffic flow on main highway and lognormalized circulation intensity for DENV-1 were independent variables; $b$ : for communities $<50 \mathrm{~km}$ away from a monitored highway provided by the National Department of Infrastructure and Transportation measured as mean daily number of passing vehicles. total number of isolates per 100,000 populations. Serum samples were to be collected within the first five days of presentation and transported to Salvador within $24 \mathrm{~h}$. This was clearly not always possible, and cases often were identified after more than five days of symptoms. Availability of roads is not an obstacle to transportation of serum samples. In order to compare the numbers of DENV isolates obtained from different municipalities, the efficiency of sample submission was calculated as in the following equation:

$$
\text { efficiency }=\text { frequency } / \text { median }
$$

where frequency is the ratio between number of sample submitted for viral isolation and the number of dengue cases registered by the $\mathrm{SSH}$, and median is the median ratio for all municipalities submitting samples. The efficiency of sample collection was then used to standardize the number of isolates per 100,000 population as calculated in the following equation:

standardized number of isolates $=$ efficiency $\mathrm{X}$ recorded number of isolates $X$ (population $X 10^{-5}$ )

For this analysis, the standardized number of isolates/ 100,000 will be a proxy for the intensity of serotypespecific viral circulation. Log transformation was used to normalize the viral circulation intensity per municipality, the number of cases of dengue, number of samples arriving at the LACEN and the number of viral isolates. Distance from Salvador was normally distributed as assessed by probability-probability plots.

Viral circulation was plotted using the program Tabwin V. 3.0.1 (http://www.datasus.gov.br/tabwin/ download.htm) from the Brazilian Ministry of Health. Data on the number of notified cases, municipal population sizes and Ae. aegypti infestation indices were provided by the BA-SSH through the Health Communication and Information Directorate (DICS). Demographic data for the state and municipalities was obtained from the National Census Bureau (IBGE, http://www.ibge.gov.br). Traffic flow data (mean number of vehicles passing per day), and distances from Salvador were obtained from the National Department of Infrastructure and Transportation. In BA, there are six electronic counting stations installed along the most important federal highways (Table I). The data from municipalities that were directly on these routes were analyzed separately from those that were located nearby. Since no qualitative differences were noted in the results, data on traffic flow for municipalities on and near $(<20 \mathrm{~km})$ the major highways was used.

Multiple linear, forward stepwise regression analysis was conducted to identify predictor variables with an inclusion criterion of $p<0.15$. Traffic flow, distance from Salvador (putative site of introduction), other viral serotypes, population size and vector infestation indices (Surveillance Epidemiology Division from SSH) were used as independent variables to explain the intensity of DENV-3 circulation. The plot of the standardized residuals against the standardized predicted values showed no patterns by visual inspection, and the probability-probability plots were essentially linear for all regression analyses. 


\section{RESULTS}

Characteristics of reporting - In 2002, the LACEN received samples from 58 of 417 municipalities in BA that also reported cases of dengue (Table II). DENV-1 or DENV-3 was isolated from $8 \%$ of the 4,777 samples received. DENV-3 isolates comprised $69 \%$ of the total. The number of samples per municipality arriving at the LACEN did not correlate with distance from Salvador $\left(\mathrm{r}^{2}=0.01\right)$, but the number of samples did correlate with the number of cases $\left(r^{2}=0.56\right)$, and the number of cases correlated with the number of viral isolates $\left(r^{2}=0.54\right)$. This analysis was performed with the values for Salvador removed. The inclusion of Salvador produced higher correlations (data not shown).

Temporal analyses - There was very active DENV-1 and DENV-2 transmission reflected in the number of viral isolates in January through April of 2001. This fell from a high of 403 in March to 23 by June (Fig. 1). Uneven and sporadic isolations continued through the end of the year. In January of 2002, there was a small rise in the total number of samples submitted (193), and only DENV-1 and DENV-2 were isolated early in the month. Significantly, on January 18 , the first recorded isolation of DENV-3 in BA was obtained from an individual living in a suburb of Salvador. Later in the month, there was a single isolation from the municipality of Valença, $100 \mathrm{~km}$ south along the coast from Salvador. Isolation of all circulating serotypes continued to increase during February and March, but isolation of DENV-3 clearly reached epidemic proportions relative to the other serotypes. Viral isolations as well as dengue cases declined steeply in April 2002.

In 2003, the initial DENV-3 isolates appeared in February instead of January. Prior to obtaining a positive sample from Salvador at the end of March 2003, the virus was isolated from eight small communities (mean population 29,000 \pm 26,000 ) each on average $>500 \mathrm{~km}$ from Salvador.

Spatial analyses - Samples were received for isolation from $15 \%(60 / 417$ and $65 / 417)$ of municipalities for both 2001 and 2002, while cases of dengue were reported from 84\% (352/417) and 94\% (391/417), respectively. In 2001, DENV-1 circulated as intensely in some distant municipalities as in Salvador (Fig. 2). DENV-2 circulated with much lower intensity and no

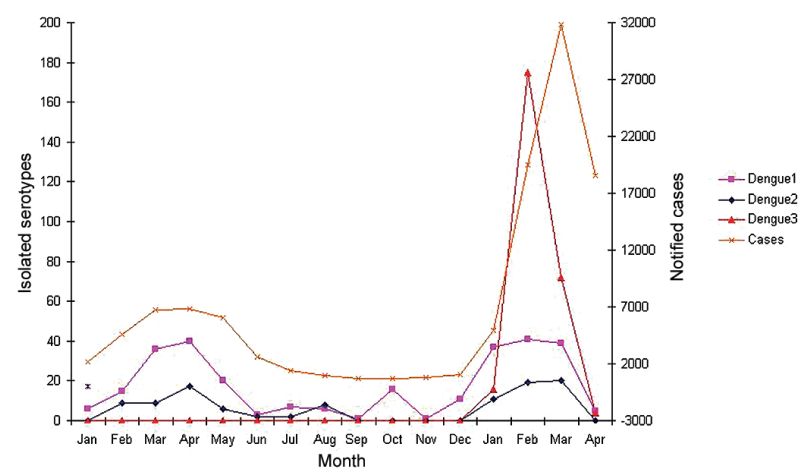

Fig. 1: monthly profile of dengue viral isolates and cases notified 2001 2002 in Bahia, Brazil.
DENV-3 was isolated. There is no indication that either virus might be distributed from a common source. Following its appearance in BA, DENV-3 circulated in many of the same municipalities as DENV-1 (Fig. 2), but Salvador is located at the center of this subsequent diffusion with the intensity of circulation generally decreasing inversely with distance from Salvador.

Following the initial isolation of DENV-3 near Salvador in January 2002, all but one of the DENV-3 isolates for the month were from Salvador as well. By February, DENV-3 was isolated from some of the most distant municipalities from Salvador (Fig. 3). The capital remained one of the most important foci throughout the rest of this quarter and remained a focus of circulation even as the epidemic waned in April. The pattern of isolations for DENV-1 and DENV-2 did not conform to this pattern in any year studied. The pattern of appearance of DENV-3 did not appear as an enlarging concentric ring around the capital, nor did it appear random within the state. An overlay of the principal highways of the state shows that these roadways extend through the municipalities from which DENV-3 was most isolated in 2002 (Fig. 4).

DENV-1 and DENV-3 in 2003 continued to circulate in generally overlapping areas, except that DENV-3 continued to be more intensely associated with Salvador than DENV-1. DENV-2 did not circulate in 2003 (data not shown), and there was no single predominant region for intensity of DENV-1 or DENV-3 circulation.

Relationship of traffic volume and distance to $D E N V$-3 circulation - Since Ae. aegypti, the vector of the dengue virus, has a very short flight range, human movement is the principal method for spread of the disease by either taking infected individuals to uninfected mosquitoes or humans carrying infected mosquitoes to where there are uninfected people (McDonald 1977, Trpis \& Hausermann 1986, Reiter et al. 1995, Getis et al. 2003, Huber et al. 2004, Harrington et al. 2005). If Salvador represented the initial focus and point of dissemination, the intensity of circulation in the state should be a function of distance from Salvador modified by the degree of human movement (migration and commercial) in the area. Linear regression was used to test this hypothesis. The log normalized intensity DENV-3 circulation was modeled with traffic flow along the main highway, distance from Salvador, log-normalized DENV-1 circulation intensity and DENV-2 circulation (Table III). The stepwise analysis revealed that a model that included (in order of significance) traffic flow and distance from Salvador produced an adjusted $\mathrm{r}^{2}=0.278$ when direct traffic flow was used $(\mathrm{p}=0.031$, Table I). The model worsened with the addition of any other variable, and the $r^{2}$ was also reduced when flow estimates were assigned to municipalities near but not directly on routes with counting stations. The coefficients for traffic flow were positive, while those for distance from Salvador were negative. The inverse square of distance was also tested, but did not improve the correlation. When DENV-1 or DENV-2 was used as the dependent variable, neither showed any significant correlations with distance or traffic volume in 2001 or 2002 (Table IV). In 2003, DENV2 did not circulate, and isolation of DENV-1 or DENV-3 did not correlate with any of the tested variables. 
TABLE II

Origin and characteristics of samples sent to Bahia's Central Laboratory (LACEN), 2002

\begin{tabular}{|c|c|c|c|c|c|c|}
\hline \multirow[b]{2}{*}{ Municipality } & \multirow[b]{2}{*}{ Population } & \multirow[b]{2}{*}{ Distance $^{a}$} & \multirow[b]{2}{*}{ Cases $^{b}$} & \multirow[b]{2}{*}{ Samples $^{c}$} & \multicolumn{2}{|c|}{ Isolates } \\
\hline & & & & & DENV $1^{d}$ & DENV-3 ${ }^{e}$ \\
\hline Alagoinhas & 132873 & 107 & 546 & 59 & 2 & 6 \\
\hline Anguera & 9039 & 146 & 119 & 21 & 0 & 1 \\
\hline Antônio Cardoso & 11681 & 139 & 11 & 3 & 1 & 0 \\
\hline Apuarema & 7268 & 353 & 65 & 3 & 0 & 1 \\
\hline Barra do Choça & 44179 & 537 & 128 & 38 & 17 & 0 \\
\hline Barreiras & 120321 & 857 & 223 & 29 & 10 & 1 \\
\hline Brumado & 62616 & 654 & 44 & 12 & 7 & 0 \\
\hline Cachoeira & 30863 & 110 & 103 & 6 & 0 & 1 \\
\hline Caculé & 20871 & 762 & 16 & 4 & 1 & 0 \\
\hline Cairu & 10609 & 308 & 22 & 2 & 0 & 0 \\
\hline Camaçari & 171845 & 41 & 718 & 15 & 0 & 2 \\
\hline Cândido Sales & 29557 & 595 & 144 & 19 & 1 & 1 \\
\hline Capela do Alto Alegre & 10795 & 208 & 3 & 3 & 1 & 0 \\
\hline Cícero Dantas & 31719 & 302 & 4 & 1 & 1 & 0 \\
\hline Coaraci & 27176 & 442 & 44 & 5 & 0 & 0 \\
\hline Conceição da Feira & 17818 & 119 & 35 & 8 & 2 & 1 \\
\hline Coração de Maria & 24214 & 104 & 748 & 169 & 1 & 9 \\
\hline Cruz das Almas & 54562 & 146 & 80 & 36 & 0 & 3 \\
\hline Feira da Mata & 6212 & 964 & 8 & 23 & 10 & 2 \\
\hline Feira de Santana & 496625 & 109 & 3214 & 809 & 12 & 13 \\
\hline Gandu & 27307 & 290 & 44 & 6 & 1 & 0 \\
\hline Ichu & 4961 & 181 & 7 & 4 & 1 & 0 \\
\hline Ipiaú & 43279 & 355 & 53 & 14 & 1 & 3 \\
\hline Ipirá & 61551 & 202 & 69 & 7 & 1 & 1 \\
\hline Itaeté & 13945 & 381 & 88 & 14 & 1 & 0 \\
\hline Itapetinga & 58868 & 571 & 67 & 7 & 0 & 1 \\
\hline Ituaçu & 17515 & 524 & 27 & 8 & 1 & 0 \\
\hline Ituberá & 24886 & 308 & 58 & 24 & 1 & 0 \\
\hline Jaguarari & 26627 & 398 & 179 & 1 & 0 & 1 \\
\hline Jequié & 147713 & 358 & 591 & 16 & 1 & 1 \\
\hline Jitaúna & 21103 & 387 & 15 & 9 & 0 & 1 \\
\hline Juazeiro & 184204 & 500 & 148 & 49 & 1 & 4 \\
\hline Lauro de Freitas & 122858 & 22 & 575 & 60 & 1 & 5 \\
\hline Macaúbas & 43120 & 682 & 39 & 19 & 2 & 1 \\
\hline Miguel Calmon & 28900 & 368 & 64 & 10 & 1 & 0 \\
\hline Monte Santo & 55240 & 352 & 89 & 18 & 0 & 1 \\
\hline Morro do Chapéu & 35068 & 386 & 43 & 8 & 1 & 0 \\
\hline Mundo Novo & 19257 & 294 & 49 & 21 & 2 & 0 \\
\hline Mutuípe & 20456 & 241 & 11 & 1 & 0 & 1 \\
\hline Piripá & 17330 & 630 & 17 & 19 & 0 & 0 \\
\hline Poções & 45555 & 444 & 5 & 1 & 0 & 0 \\
\hline Pojuca & 26960 & 67 & 35 & 25 & 0 & 2 \\
\hline Prado & 27311 & 787 & 37 & 2 & 0 & 0 \\
\hline Salvador & 2520504 & 0 & 29309 & 2723 & 34 & 183 \\
\hline Salinas da Marg & 13154 & 229 & 60 & 3 & 0 & 2 \\
\hline Santo Antônio de Jesus & 80111 & 185 & 0 & 16 & 0 & 1 \\
\hline São Miguel das Matas & 10169 & 224 & 11 & 5 & 0 & 1 \\
\hline São Sebastião do Passe & 40620 & 58 & 247 & 39 & 2 & 2 \\
\hline Sátiro Dias & 18003 & 205 & 12 & 5 & 0 & 0 \\
\hline Saúde & 11509 & 353 & 7 & 1 & 0 & 1 \\
\hline Simoes Filho & 98598 & 22 & 1061 & 55 & 0 & 3 \\
\hline Taperoá & 15699 & 282 & 15 & 4 & 1 & 0 \\
\hline Uauá & 26340 & 416 & 8 & 5 & 0 & 1 \\
\hline Ubaitaba & 24441 & 369 & 28 & 3 & 1 & 0 \\
\hline Valença & 79735 & 262 & 172 & 45 & 0 & 2 \\
\hline Vera Cruz & 31352 & 289 & 143 & 20 & 0 & 3 \\
\hline Vitória da Conquista & 270364 & 509 & 714 & 154 & 1 & 3 \\
\hline Xique-Xique & 45632 & 577 & 99 & 91 & 0 & 0 \\
\hline
\end{tabular}

$a$ : distance from Salvador in $\mathrm{km} ; b$ : cases of dengue officially reported to the State Secretariat of Health; $c$ : samples is the number of samples sent to the LACEN for processing; $d$ : DENV-1 isolates is the number of samples producing this serotype; $e$ : DENV-3 isolates is the number of samples producing this serotype. There were no DENV-2 isolates in 2002. 


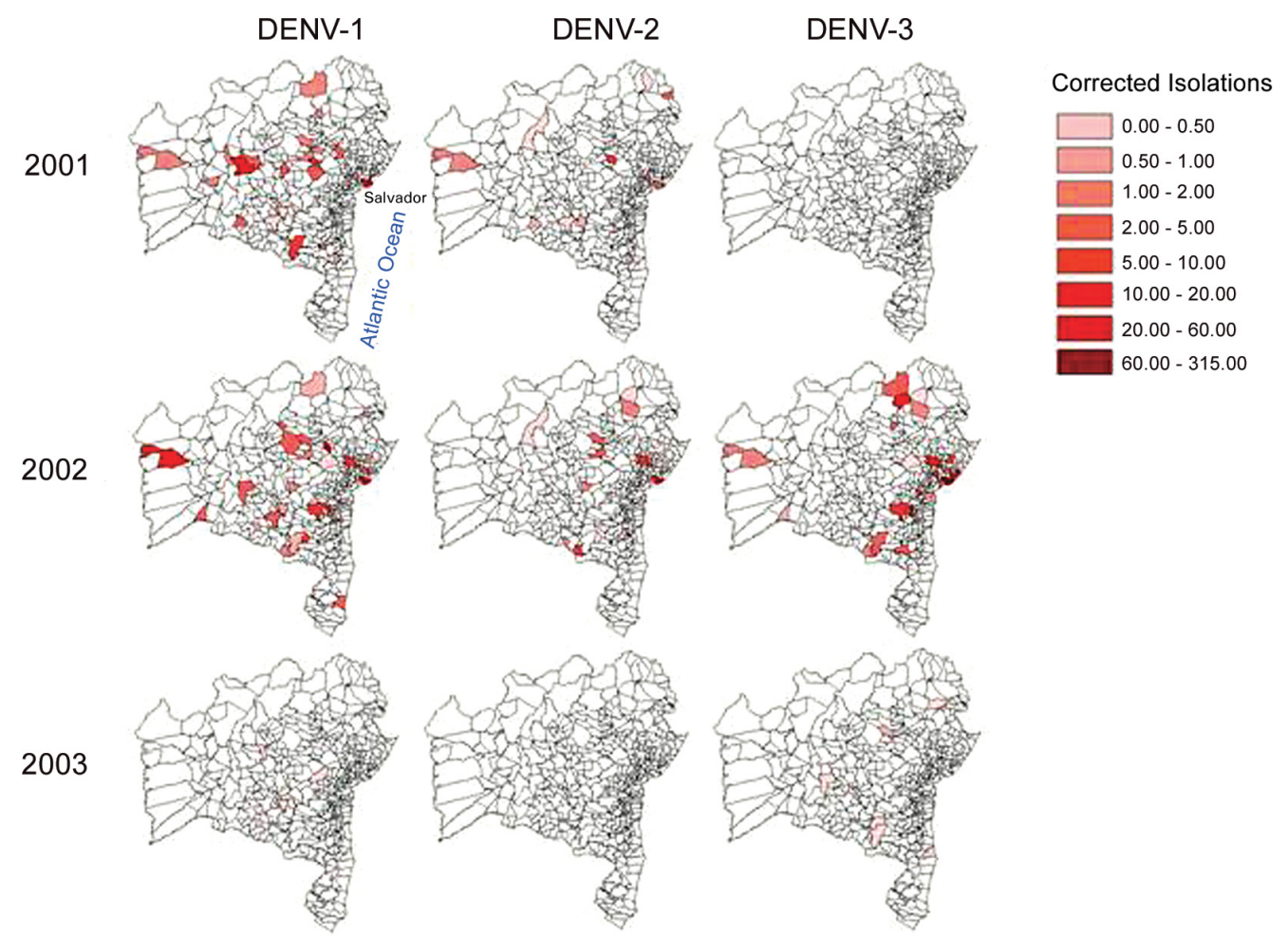

Fig. 2: comparison of yearly intensity of dengue virus serotypes circulation (DENV-1, 2 and 3) 2001 - 2003 in Bahia, Brazil. Maps of state of Bahia municipalities (www.datasus.gov.br/tabwin/tabwin.htm) by year and by serotype showing intensity of viral circulation (standardized number of viral isolations) indicated in legend.
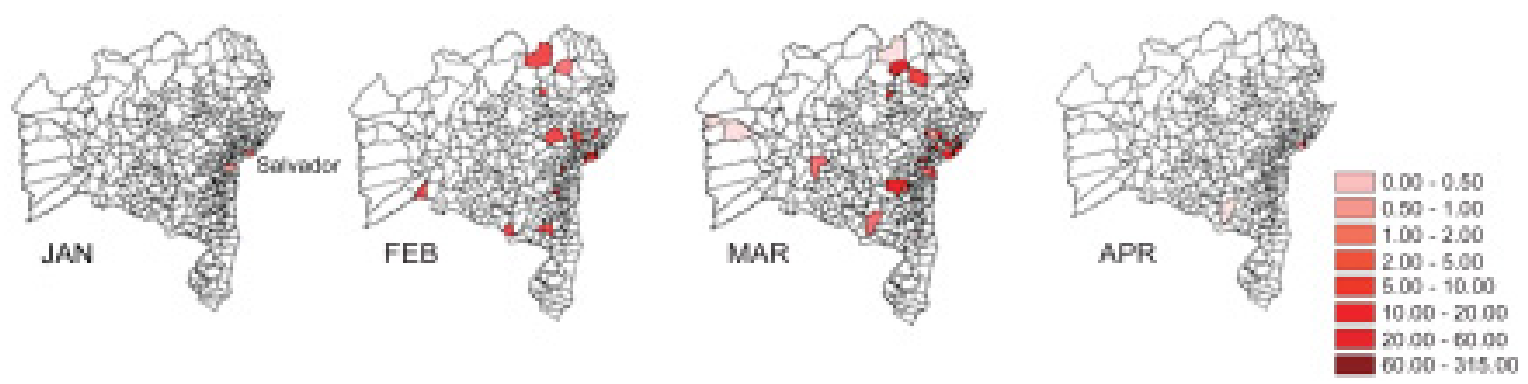

Fig. 3: comparison of monthly intensity of dengue serotype 3 (DENV-3) circulation (standardized isolates/100,000), Jan-Apr 2002 in Bahia, Brazil.

Additional factors associated with intensity of DENV-3 circulation - Traffic volume and distance from Salvador explain approximately $27 \%$ of the variation in DENV-3 circulation intensities in 2002. To assess the contribution of other factors, both population size and municipal vector infestation indices (household and Breteau) were included in the model. The size of the population had the largest effect of any variable, and produced a model with $\mathrm{r}^{2}=0.565, \mathrm{p}=0.0003$ (Table V). The variables traffic volume, distance from Salvador and $\log$ of the standardized DENV-1 circulation also entered into the model, but neither of the infestation indices contributed. The $\mathrm{r}^{2}$ was reduced when traffic volume was removed $\left(\mathrm{r}^{2}=0.431\right)$ or the estimated traffic volume for municipalities not directly on monitored routes was used $\left(\mathrm{r}^{2}=0.488\right)$. Collinearity diagnostics showed that population and traffic volume were independent, and thus traffic volume was not merely a surrogate for population size. For this epidemic: DENV-3 circulation $=0.663$ $+(0.574)$ population size $+(0.190)$ traffic volume + $(-0.266)$ distance from Salvador $+(0.158) \log _{10}$ other viral circulation.

\section{DISCUSSION}

The dengue epidemic of 2002 was the most severe yet experienced BA. The first recorded cases of DHF occurred during this period. Although the epidemic spike was clearly due to the introduction of DENV-3, the stage was set by a previous decade of spreading Ae. aegypti infestation and DENV-1 and DENV-2 in- 


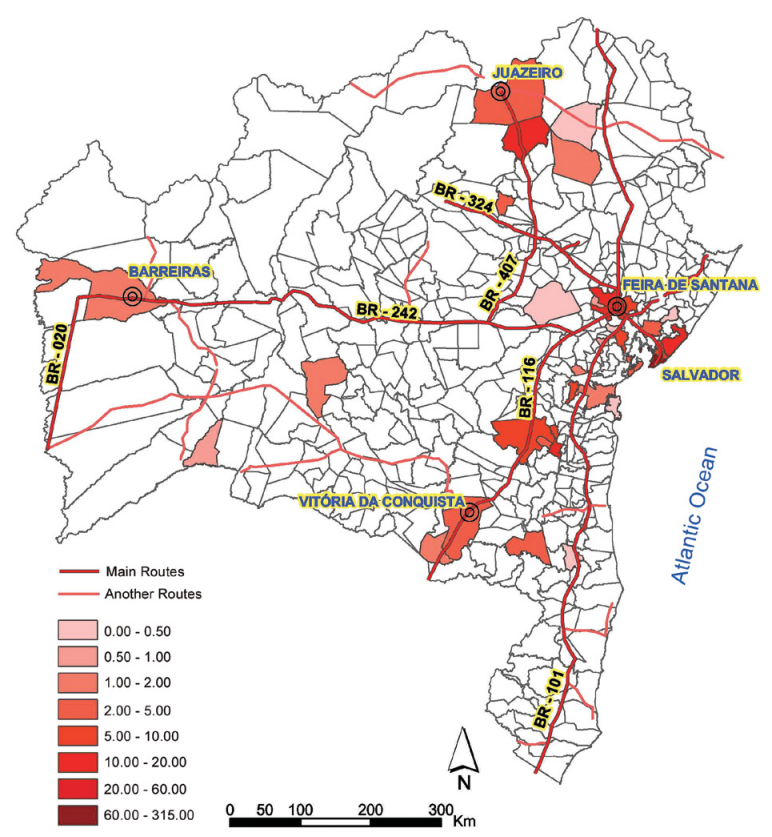

Fig. 4: main transportation routes and spatial distribution of dengue serotype 3 (DENV-3) intensity (standardized isolates/100,000) in Bahia, 2002. fections. Thus, prior to the introduction of DENV-3, $69 \%$ of the population of Salvador was seropositive for at least one dengue virus (Teixeira et al. 2002). Viral isolation from clinical samples was instituted in the LACEN after DENV-1 and DENV-2 began to circulate, so that the 2002 epidemic was the first that could be tracked state-wide from its introduction. The institution of state-wide viral isolations was an essential tool in the epidemiology of this disease, since the registration of dengue cases alone does not allow for a reconstruction of what was occurring and how it occurred in the presence of multiple circulating serotypes.

Both time and space place the introduction of DENV-3 infection in Salvador in January 2002. For two weeks this serotype was only isolated from infected individuals in Salvador despite continued receipt of samples and isolation of other serotypes from all corners of BA. The next site for the dissemination of the virus was the transportation hub of Feira de Santana, $40 \mathrm{~km}$ west of the capital. In less than 30 days this virus was distributed to the rest of the state. Even after its introduction and dissemination, the capital remained the site of the most intense circulation of DENV-3, but not necessarily the other serotypes. The significant positive correlation with traf-

TABLE III

Distance and estimated traffic volume used for municipalities with DENV isolations, 2002

\begin{tabular}{|c|c|c|c|c|c|}
\hline City & Traffic $^{a}$ & Distance $^{b}$ & City & Traffic & Distance \\
\hline Alagoinhas & $2357^{c}$ & 107 & Jequié & 6863 & 358 \\
\hline Anguera & 9525 & 146 & Jitaúna & 4530 & 387 \\
\hline Antônio Cardoso & 9525 & 139 & Juazeiro & 3712 & 500 \\
\hline Apuarema & 7961 & 353 & Lauro de Freitas & 9525 & 22 \\
\hline Barra do Choça & 6863 & 537 & Macaúbas & 3712 & 682 \\
\hline Barreiras & 817 & 857 & Miguel Calmo & - & 368 \\
\hline Brumado & $-d$ & 654 & Monte Santo & - & 352 \\
\hline Cachoeira & 2357 & 110 & Morro do Chapeu & - & 386 \\
\hline Caculé & - & 762 & Mundo Novo & 3712 & 294 \\
\hline Cairu & 2357 & 308 & Mutuípe & 2357 & 241 \\
\hline Camacan & 2196 & 526 & Piripá & - & 630 \\
\hline Camaçari & 9525 & 41 & Poções & 6863 & 444 \\
\hline Cândido Sale & 6863 & 595 & Pojuca & - & 67 \\
\hline Capela do Alto Alegre & 3712 & 208 & Prado & - & 787 \\
\hline Cícero Dantas & - & 302 & Salinas da Margarida & 2357 & 229 \\
\hline Coaraci & 2196 & 442 & Salvador & 9525 & 0 \\
\hline Conceição da Feira & 2357 & 119 & Santo Antônio DJ & 2357 & 185 \\
\hline Coração de Maria & 2357 & 104 & São Miguel das Matas & 2357 & 224 \\
\hline Cruz das Almas & 2357 & 146 & São Sebastiã & 9525 & 58 \\
\hline Dom Basílio & 817 & 709 & Sátiro Dias & - & 205 \\
\hline Feira da Mata & 817 & 964 & Saúde & 3712 & 353 \\
\hline Feira de Santana & 9525 & 109 & Simoes Filho & 9525 & 22 \\
\hline Gandu & 2357 & 290 & Taperoá & 2357 & 282 \\
\hline Ichu & - & 181 & Uauá & - & 416 \\
\hline Ipiaú & 7961 & 355 & Ubaitaba & 2196 & 369 \\
\hline Ipirá & 817 & 202 & Valença & 2357 & 262 \\
\hline Itaeté & - & 381 & Varzedo & 2357 & 189 \\
\hline Itapetinga & - & 571 & Vera Cruz & 9525 & 289 \\
\hline Ituaçu & - & 524 & Vitória da C & 6863 & 509 \\
\hline Ituberá & 2357 & 308 & Xique-Xique & - & 577 \\
\hline Jaguarari & 3712 & 398 & & & \\
\hline
\end{tabular}

$a$ : mean daily volume as measured in 2001 by fixed electronic sensors at six stations (Table I); $b$ : distance from Salvador; $c$ : values in bold indicate municipalities directly on the monitored routes; $d$ : municipalities too distant from monitored routes to estimate traffic flow. 
TABLE IV

Distance from Salvador and traffic flow correlate only with dengue virus serotype 3 (DENV-3) circulation and only in $2002^{a}$

\begin{tabular}{cccc}
\hline Year & DENV-1 Adjusted $\mathrm{r}^{2}(\mathrm{p})$ & ${\text { DENV-2 Adjusted } \mathrm{r}^{2}(\mathrm{p})}$ & ${\text { DENV-3 Adjusted } \mathrm{r}^{2}(\mathrm{p})}$ \\
\hline 2001 & $0.001(0.388)$ & $0.038(0.287)$ & (Not circulating) \\
2002 & $0.015(0.262)$ & $-0.038(0.923)$ & $0202(0.002)$ \\
2003 & $-0.310(0.949)$ & (Not circulating) & $-0.165(0.666)$ \\
\hline
\end{tabular}

$a$ : linear multiple regression where the dependent variable is viral circulation (standardized isolates/100,000) per municipality and the independent variables are distance from Salvador $(\mathrm{km})$ and traffic flow (mean daily number of passing vehicles on the major highway $<50 \mathrm{~km}$ away).

\section{TABLE V}

Linear multiple regression analysis of dengue virus serotype 3 (DENV-3) circulation in 2002

\begin{tabular}{lcc}
\hline Model $^{a}$ & Adjusted $\mathrm{r}^{2}$ & $\mathrm{P}$ \\
\hline Population $^{b}$ & 0.399 & $<10^{-5}$ \\
Population, traffic flow & 0.490 & $<10^{-6}$ \\
Population, traffic flow, distance & 0.487 & $<10^{-5}$ \\
Population, traffic flow, & & \\
distance, logDENV-1 & & \\
\hline
\end{tabular}

$a$ : both of Ae. aegypti infestation indices (household and Breteau) failed to enter into the model; $b$ : population size from the 2000 National Census, traffic flow (mean daily number of passing vehicles on the major highway $<50 \mathrm{~km}$ away) and distance from Salvador $(\mathrm{km}) ; c$ : log-normalized circulation intensity of DENV-1 and DENV3 were used.

fic flow, the negative correlation with distance from Salvador, the absence of this pattern for the serotypes already present and for DENV-3 in the following year all support the hypothesis that Salvador was the center of distribution for DENV-3 during the 2002 epidemic.

While it may not be surprising that this virus would follow the major transportation routes out of the capital, this was not the pattern for the introduction and distribution of DENV-1 and DENV-2 (Vasconcelos et al. 2000). These two were introduced in smaller cities in the state and had a less clear pattern for subsequent distribution. One important factor in the more halting spread for those earlier introductions was that the distribution of Ae. aegypti was less extensive. From the time of first introduction of dengue in the state (1987) up to 2001, the number of municipalities reporting Ae. aegypti infestation in Brazil increased by $800 \%$ (Teixeira et al. 2001). Infected individuals traveling to a new area in the 1980 s and 1990s were not as likely to encounter a vector as in 2002.

The low percent of municipalities sending samples for viral isolation may have produced a bias toward collections from population and transportation centers and this might have explained the pattern for isolations in 2002. However, no such pattern was observed for 2001 when there was a similar percentage of municipalities providing samples. In addition, those collecting samples had no idea of the serotype of the infecting virus, but only DENV-3 demonstrated a distribution associated with distance from Salvador and traffic flow.

Although a vector-borne disease, the pattern of spread of DENV-3 in BA in 2002 has some features in common with a point source introduction and subsequent distribution of a new pathogen with person-to-person spread. The mosquito vector, Ae. aegypti, has a short flight range, so that its own movements are unlikely to contribute much to the rapid distribution of this serotype of dengue (McDonald 1977, Trpis \& Hausermann 1986, Reiter et al. 1995, Getis et al. 2003, Huber et al. 2004, Harrington et al. 2005). The heavy dependence of this infection on human movement and, indirectly, human contact may make the distribution of new dengue serotypes a model for the introduction of diseases that require person-to-person spread. While the movement of the human population is often cited a key to dengue transmission (Rodhain 1992, Pinheiro \& Corber 1997, da Costa-Ribeiro et al. 2006), models of dengue transmission, however, often fail to include human mobility as an explanatory factor (Newton \& Reiter 1992, Focks et al. 1995, 2000, Lifson 1996, Atkinson et al. 2007). Our findings further support the central role of the human population in viral dissemination.

The greatest weakness of these data is that they are secondary or relatively incomplete. Thus, the results must be viewed with caution. Nonetheless, lack of correlation between numbers of serum samples received and distance from the LACEN in Salvador as well as the correlation between number of samples received and number of cases of dengue indicate that the data are not random or a function of convenience. They likely represent the intensity of viral circulation. While distance was measured with good accuracy, traffic volume was sometimes assigned based on some distant point of measurement. Since misspecification lowers the power and significance of analyses, it is likely that more accurate measurements would produce even stronger correlations. Distance and traffic flow, however, only explained $28 \%$ of the variance. Clearly there were other factors that could influence this pattern. One of these was population size. The intensity of viral circulation was strongly dependent on density and availability of susceptible individuals. Vector density did not correlate well with intensity of viral circulation in this study.

One issue related to this being a "new" virus for this population was the active circulation of two other dengue serotypes. There is a brief period of two months following acute infection in which immunity develops to all dengue serotypes (Sabin 1952), so co-circulation of two serotypes might interfere with the spread of a third serotype. From the regression analysis, however, the co-circulation of other DENV did not lead to rela- 
tive inhibition of DENV-3. DENV-1 circulation was in fact positively correlated with DENV-3 circulation. This might suggest that the factors that allowed DENV-1 to circulate successfully may have also promoted DENV-3 circulation to overcome whatever degree of cross-immunization that might have existed. On the other hand, no cases of dual infection were detected, which may suggest some interference, albeit the viral isolation method may be insensitive to dual infection.

Finally, the analysis of new introductions is very important to the study of the dynamics of viral diseases, since even one year after the introduction, understanding the pattern of dissemination becomes more complex. The level of immunity in the population must be accounted for. Thus, the opportunity to analyze this circumstance again any time soon in Brazil will only present itself with the introduction of DENV-4 or another new disease.

\section{ACKNOWLEDGMENTS}

To the Biomedical Section of the State Central Laboratory of Bahia (LACEN), as well as Emanuel Araújo and Jesuina Costa and other staff members in SESAB for epidemiologic data. To Dr. M Gloria Teixeira for her useful information on patterns of vector distribution within the state.

\section{REFERENCES}

Atkinson MP, Su Z, Alphey N, Alphey LS, Coleman PG, Wein LM 2007. Analyzing the control of mosquito-borne diseases by a dominant lethal genetic system. Proc Natl Acad Sci USA 104: 9540-9545.

da Costa-Ribeiro MC, Lourenco-de-Oliveira R, Failloux AB 2006. Geographic and temporal genetic patterns of Aedes aegypti populations in Rio de Janeiro, Brazil. Trop Med Int Health 11: $1276-1285$.

Figueiredo LT 2000. The Brazilian flaviviruses. Microbes Infect 2: $1643-1649$.

Focks DA, Brenner RJ, Hayes J, Daniels E 2000. Transmission thresholds for dengue in terms of Aedes aegypti pupae per person with discussion of their utility in source reduction efforts. Am J Trop Med Hyg 62: 11-18.

Focks DA, Daniels E, Haile DG, Keesling JE 1995. A simulation model of the epidemiology of urban dengue fever: literature analysis, model development, preliminary validation, and samples of simulation results. Am J Trop Med Hyg 53: 489-506.

Getis A, Morrison AC, Gray K, Scott TW 2003. Characteristics of the spatial pattern of the dengue vector, Aedes aegypti, in Iquitos, Peru. Am J Trop Med Hyg 69: 494-505.

Gubler DJ, Kuno G, Sather GE, Velez M, Oliver A 1984. Mosquito cell cultures and specific monoclonal antibodies in surveillance for dengue viruses. Am J Trop Med Hyg 33: 158-165.

Guzman MG, Kouri G 2002. Dengue: an update. Lancet Infect Dis 2: 33-42.

Harrington LC, Scott TW, Lerdthusnee K, Coleman RC, Costero A, Clark GG, Jones JJ, Kitthawee S, Kittayapong P, Sithiprasasna R, Edman JD 2005. Dispersal of the dengue vector Aedes aegypti within and between rural communities. Am J Trop Med Hyg 72: 209-220.

Huber K, Loan LL, Chantha N, Failloux AB 2004. Human transportation influences Aedes aegypti gene flow in Southeast Asia. Acta Trop 90: 23-29.

Lifson AR 1996. Mosquitoes, models, and dengue. Lancet 347 : 1201-1202.

Mackenzie JS, Gubler DJ, Petersen LR 2004. Emerging flaviviruses: the spread and resurgence of Japanese encephalitis, West Nile and dengue viruses. Nat Med 10: S98-109.

McBride WJ, Bielefeldt-Ohmann H 2000. Dengue viral infections; pathogenesis and epidemiology. Microbes Infect 2: 1041-1050.

McDonald PT 1977. Population characteristics of domestic Aedes aegypti (Diptera: Culicidae) in villages on the Kenya Coast I. Adult survivorship and population size. J Med Entomol 14: $42-48$.

Newton EA, Reiter P 1992. A model of the transmission of dengue fever with an evaluation of the impact of ultra-low volume (ULV) insecticide applications on dengue epidemics. Am J Trop Med Hyg 47: 709-720.

PAHO - Pan American Health Organization 2003. Surveillancefeatured surveillance items. http://www.paho.org/english/ad/ $\mathrm{dpc} / \mathrm{cd} /$ dengue.html [cited 2003 Nov 23].

Pinheiro FP, Corber SJ 1997. Global situation of dengue and dengue haemorrhagic fever, and its emergence in the Americas. World Health Stat Q 50: 161-169.

Reiter P, Amador MA, Anderson RA, Clark GG 1995. Short report: dispersal of Aedes aegypti in an urban area after blood feeding as demonstrated by rubidium-marked eggs. Am J Trop Med Hyg 52: 177-179.

Rodhain F 1992. Recent data on the epidemiology of dengue fever. Bull Acad Natl Med 176: 223-236.

Sabin AB 1952. Research on dengue during World War II. Am J Trop Med Hyg 1: 30-50.

Teixeira MG, Barreto ML, Costa M da C, Ferreira LD, Vasconcelos PF, Cairncross S 2002. Dynamics of dengue virus circulation: a silent epidemic in a complex urban area. Trop Med Int Health 7: 757-762.

Teixeira MG, Costa MC, Barreto ML, Barreto FR 2001. Epidemiology of dengue in Salvador-Bahia, 1995-1999. Rev Soc Bras Med Trop 34: 269-274.

Trpis M, Hausermann W 1986. Dispersal and other population parameters of Aedes aegypti in an African village and their possible significance in epidemiology of vector-borne diseases. Am J Trop Med Hyg 35: 1263-1279.

Vasconcelos PF, Mota K, Straatmann A, Santos-Torres S, Travasso da Rosa AP, Tavares Neto J 2000. A dengue epidemic in Ipupiara and Prado, Bahia. A seroepidemiologic survey. Rev Soc Bras Med Trop 33: 61-67.

Wang E, Ni H, Xu R, Barrett AD, Watowich SJ, Gubler DJ, Weaver SC 2000. Evolutionary relationships of endemic/epidemic and sylvatic dengue viruses. $J$ Virol 74: 3227-3234. 